\title{
重水素標識機能性材料の網羅的合成を目指して
}

\author{
澤 間善成
}

\section{Exhaustive Syntheses of Deuterium-labelled Compounds}

\author{
Yoshinari Sawama ${ }^{\dagger}$ \\ Gifu Pharmaceutical University; 1-25-4 Daigaku-nishi, Gifu 501-1196, Japan.
}

(Received August 15, 2021)

\begin{abstract}
Deuterium $\left({ }^{2} \mathrm{H}, \mathrm{D}\right)$ is a stable isotope of hydrogen $\left({ }^{1} \mathrm{H}\right)$. Deuterium-incorporated (labelled) compounds are widely utilized in various scientific fields such as mechanistic studies of organic reactions, elucidation of drug metabolism, application as tracers for microanalysis. Recently, development of heavy drugs and molecular imaging using techniques such as neutron scattering and Raman spectroscopy are spotlighted. We have developed various deuterium-incorporated compounds using $\mathrm{D}_{2} \mathrm{O}$ as an inexpensive deuterium source to construct novel functional materials. The use of platinum group metals on carbon as catalysts could result in the multi-deuteration of compounds in the mixed solvents of 2propanol and $\mathrm{D}_{2} \mathrm{O}$, and site-selectively deuterated compounds can be synthesized by organocatalytic methods. In this review, the latter deuteration methods using organocatalysts and their applications are summarized. Terminal alkynes smoothly underwent deuterium incorporation by using triethylamine as an organic base or a solid resin possessing the tertiary amine moiety in the same molecule to give mono-deuterated alkynes. These compounds were partially reduced over our prepared specific palladium catalyst under atmospheric $\mathrm{D}_{2}$ gas to produce tri-deuterated alkenes. Achiral or chiral di-deuterated $\beta$-nitro alcohols were also prepared by the organic-base-catalyzed deuteration of nitromethane, followed by nitroaldol reactions in a one pot manner. The mono-deuteration of aromatic aldehyde could be effectively catalyzed by $N$-heterocyclic carbene. Furthermore, the $\alpha$-deuteration of aliphatic aldehydes using a basic resin catalyst and the subsequent Knoevenagel condensation with malononitrile could provide $\gamma$-deuterium-incorporated $\alpha, \beta$-unsaturated nitrile derivatives. The deuterated compounds thus obtained can be important synthetic precursors to construct the deuterium-incorporated target functional materials.
\end{abstract}

Key words_- deuterium; isotope; organocatalyst; synthetic precursor

\section{1. はじめに}

重水素 $\left({ }^{2} \mathrm{H}, \mathrm{D}\right)$ は，水素 $\left({ }^{1} \mathrm{H}\right)$ の放射性のない 安定同位体である。 また，重水素原子が導入された 有機化合物（重水素置換体）は，同位体標識化合物 として微量分析のトレーサーや医薬品の体内動態追 跡などに古くより用いられてきた。最近では，C-D 結合は C-H 結合より安定であるという同位体効果 を利用した重水素化医薬品（ヘビードラッグ）が注 目されている.1) すなわち，チトクローム $\mathrm{p} 450$ によ り酸化的に代謝される医薬品構造の C-H 結合部位 を安定な C-D 結合に置換することで代謝安定性が

岐阜薬科大学（干501-1196 岐阜市大学西 1-25-4)

現所属: ‘大阪大学大学院薬学研究科 (T565-0871 大 阪府吹田市山田丘 1-6)

e-mail: sawama@phs.osaka-u.ac.jp

本総説は, 日本薬学会第 141 年会シンポジウムS11 で 発表した内容を中心に記述したものである.
向上する，その結果，用法・用量の削減や毒性の軽 減につながるメリットが生まれる。昨今, 機器分析 装置の性能が飛躍的に進歩しており，中性子散

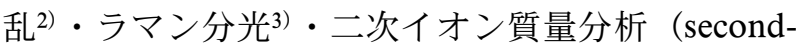
ary ion mass spectrometry; SIMS) ${ }^{4)}$ などを用いた解 析に重水素置換体が適用されている. 重水素置換体 の需要は益々高まることが予想され，有機分子への 重水素原子導入法の開発が世界中で活発に実施され ている. ${ }^{5-9)}$ われわれは，最も安価な重水素源であ る重水 $\left(\mathrm{D}_{2} \mathrm{O}\right)$ を用いた多様な重水素置換法を開発 してきた. ${ }^{9-15)} \mathrm{Pt} / \mathrm{C}$ などの不均一系白金族触媒存在 下 2-PrOH と $\mathrm{D}_{2} \mathrm{O}$ の混合溶媒中で反応させると, 芳香族化合物 ${ }^{11,12)}$ やアルカン, ${ }^{13)}$ 飽和脂肪酸, 14) ア クリル酸15)などの多重重水素化が進行する。一方, 医薬品や機能性材料の重水素置換体を合成する上 で，用途に合わせて部分的に重水素原子を導入する 技術が重要である。そこで本総説では，有機触媒を 


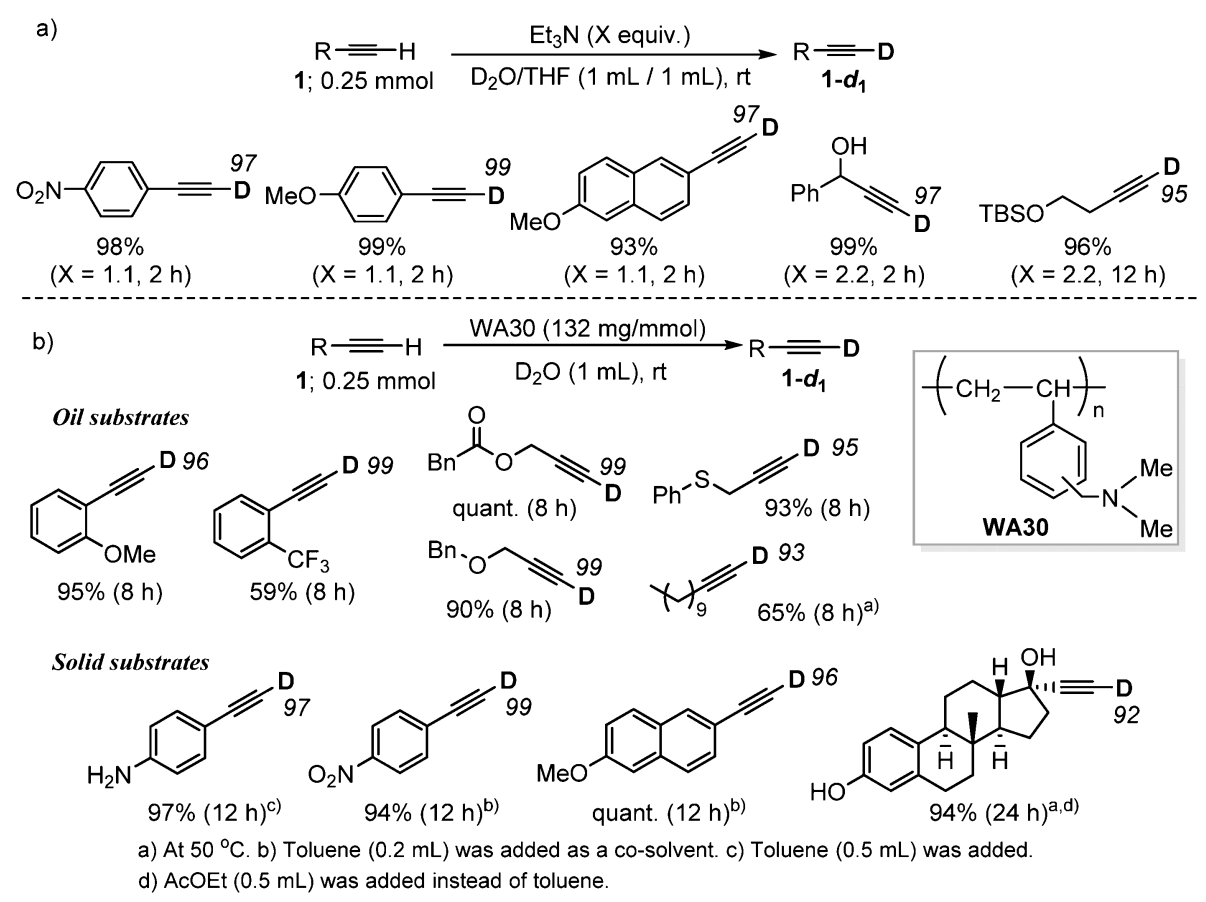

Fig. 1. Organic-base-mediated Deuterium Incorporation of Terminal Alkynes

用いた部分的重水素化と応用についてまとめさせて 頂 $<.{ }^{16-20)}$

\section{2. 有機触媒と重水を用いた重水素原子導入反応} 之応用

2-1. 末端アルキンの重水素化アルキンは官 能基変換性に優れているため，末端アルキンのモノ 重水素化体（Fig. 1，1- $\boldsymbol{d}_{\mathbf{1}}$ ）は重水素化ターゲット分 子の合成前駆体として有用である。一般に，末端ア ルキンに対して化学量論量のブチルリチウム（nBuLi）などを作用させて金属アセチリドを形成後, $\mathrm{D}_{2} \mathrm{O}$ で処理することで $\mathbf{1}-\boldsymbol{d}_{\mathbf{1}}$ が合成できる，当論量 の金属廃棄物が排出されるとともに，アセチリド形 成時には脱水有機溶媒が必要とされる問題がある. われわれは,トリエチルアミン $\left(\mathrm{Et}_{3} \mathrm{~N}\right)$ 存在下 $\mathrm{D}_{2} \mathrm{O}$ とテトラヒドロフラン (THF) の混合溶媒中, 室 温で靦汼するのみで，末端アルキン（1）に重水素 原子が導入されることを見い出した $\left[\right.$ Fig. 1(a) ]. ${ }^{16)}$ また，第三級アミンを分子内に持つスチレン系樹脂 WA30を触媒とした手法にも応用した [Fig. 1

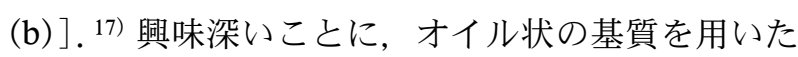
場合には $\mathrm{D}_{2} \mathrm{O}-\mathrm{WA} 30$-基質の三層系にもかかわら ず，効率的に目的の $1-d_{1}$ が生成した。一方，固体 基質を用いた反応には，トルエン等の有機溶媒を添 加することで末端アルキンのモノ重水素化が円滑に
進行することを明らかとした。WA30 はろ過によ り容易に回収でき，触媒活性を低下することなく再 利用することが可能である.

また，アルキン体（1）若しくはアルキンモノ重 水素化体（1- $\left.d_{1}\right)$ を基質にして，重水素ガス $\left(\mathrm{D}_{2}\right)$ 雾囲気下部分還元することで位置選択的に重水素原 子が導入されたオレフィン化合物（2- $\left.\boldsymbol{d}_{\mathbf{1}}, \mathbf{2}-\boldsymbol{d}_{\mathbf{2}}, \mathbf{2}-\boldsymbol{d}_{\mathbf{3}}\right)$ が合成できる $\left[\right.$ Fig. 2(a)]. ${ }^{16)} \mathrm{D}_{2}$ は戦略物質として 指定されており，高価であるとともに輸入量が制限 されている（最近，わが国でも購入可能となってい る)。そこで，この反応では岐阜薬科大学・佐治木 弘尚教授により開発された $\mathrm{Pd} / \mathrm{C}$ 触媒存在下 $\mathrm{D}_{2} \mathrm{O}$ と $\mathrm{H}_{2}$ を用いた $\mathrm{D}_{2}$ の用時調製法を利用した [Fig. 2 (b) ]. ${ }^{21)}$ また，部分還元触媒としてわれわれが独自 に開発した窒化ホウ素（boron nitride; BN）担持型

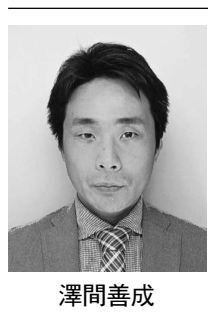

2006 年大阪大学大学院薬学研究科博士 課程修了，2005 年日本学術振興会特別 研究員 $(D C 2, P D), 2007$ 年独国ドル トムント工科大学化学科博士研究員, 2009 年立命館グローバルイノベーショ ン研究機構博士研究員兼大阪大学薬学 部特任助教, 2010 年より岐阜薬科大学 助教，講師，准教授を経て，2021 年よ り現職・大阪大学大学院薬学研究科准 教授として従事. 


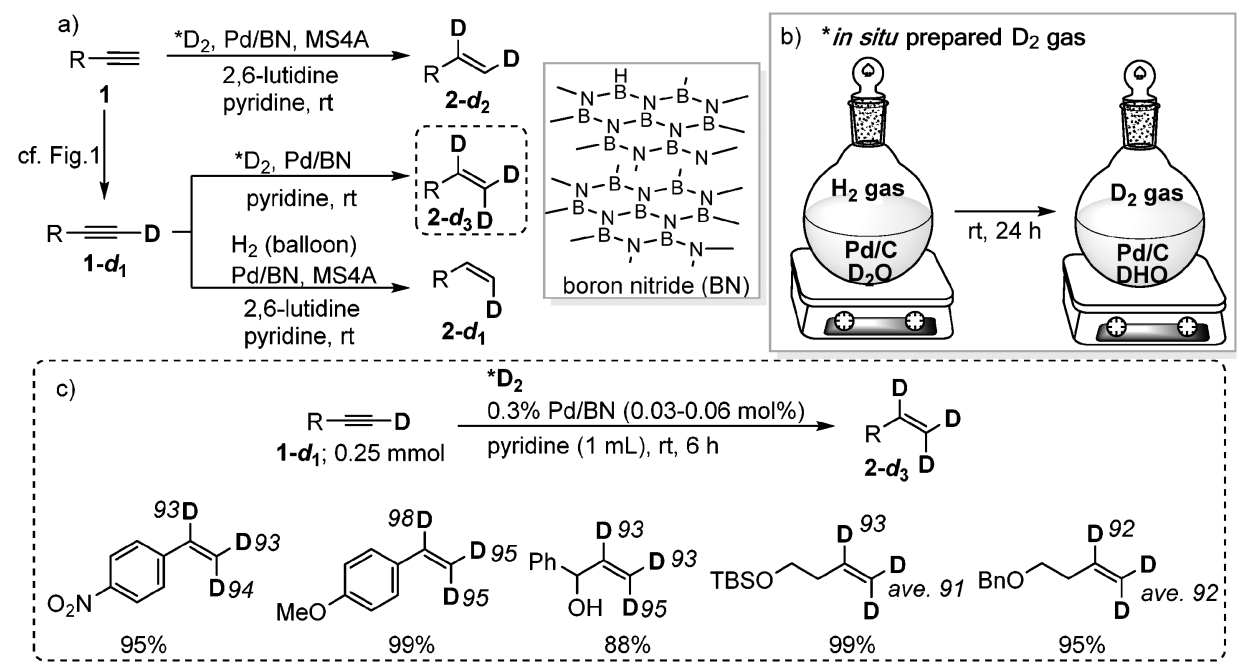

Fig. 2. Reductive Deuteration of Alkynes Using in Situ Prepared $\mathrm{D}_{2}$ Gas
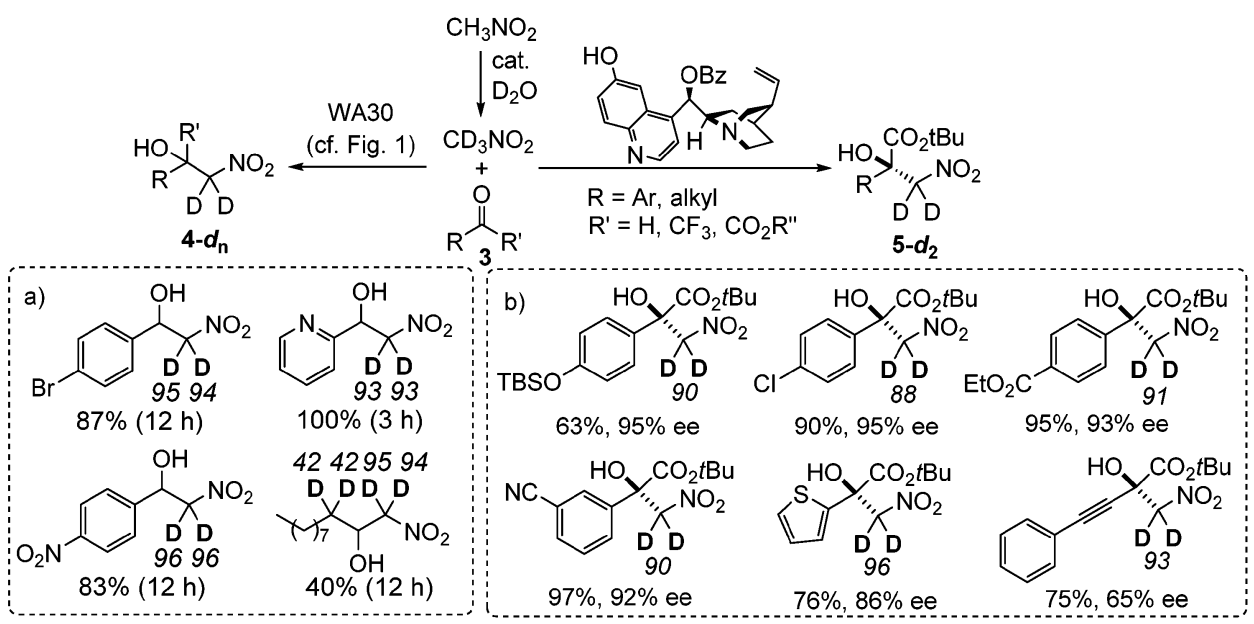

Fig. 3. Nitroaldol Reactions Accompanied with the Deuteration of Nitromethane

パラジウム触媒（ $\mathrm{Pd} / \mathrm{BN})$ を用いている，塩基性 条件下 $\mathrm{Pd} / \mathrm{BN}$ を触媒として接触水素化すると，末 端並びに内部アルキンは対応するアルケン体に効率 よく部分還元される. ${ }^{22,23)}$ 一例を示すと, $\mathrm{Pd} / \mathrm{BN}$ 触媒存在下ピリジン溶媒中, 用時調製した $\mathrm{D}_{2}$ を反 応フラスコ内に導入することで, $1-d_{1}$ の還元的重水 素化が効率的に進行し重水素原子が 3 つ導入された アルケン（2-d $\left.d_{3}\right)$ が合成できた [Fig. 2(c) ].

2-2. ニトロメタンの重水素化に続くニトロアル ドール反応 ニトロメタンは塩基性条件下求核種 として機能するため, 重ニトロメタン $\left(\mathrm{CD}_{3} \mathrm{NO}_{2}\right)$ は重水素化メチレン部位を導入するための強力な ツールとなる。しかし，高価であるため工業スケー ルでの適用は困難である。 そこでわれわれは， $\mathrm{D}_{2} \mathrm{O}$ 中塩基性条件下ニトロメタンから重ニトロメタンを
用時調製し，直接カルボニル化合物（3）に求核付 加させることで $\beta$ 位に 2 つ重水素原子が導入さ れたニトロアルコール類（Fig. 3， 4- $d_{\mathbf{n}}, 5-d_{2}$ ) が合 成できるものと考えた。 スチレン系塩基性樹脂 WA30（Fig. 1）を用いた際には，芳香族アルデヒ ドや脂肪族アルデヒドに対して所望の反応が進行 し, 高重水素化率で 4- $\boldsymbol{d}_{\mathbf{n}}$ が得られた [Fig. $3(\mathrm{a})$ ]. ${ }^{18)}$ なお，脂肪族アルデヒドを基質にしたときは，アル デヒドの $\alpha$ 位重水素化も併発しテトラ重水素化体 が生成した。生成物は, 重水素化率を低下させるこ となく多様な骨格に変換可能である。一方，キニー ネ誘導体を触媒とすることで，ベンゾイルギ酸ター シャリーブチル（3: $\left.\mathrm{R}=\operatorname{aryl}, \mathrm{R}^{\prime}=\mathrm{CO}_{2} t-\mathrm{Bu}\right)$ に対 するニトロメタンの重水素化を伴うニトロアルドー ル反応が高立体選択的に進行し，目的のキラル化合 


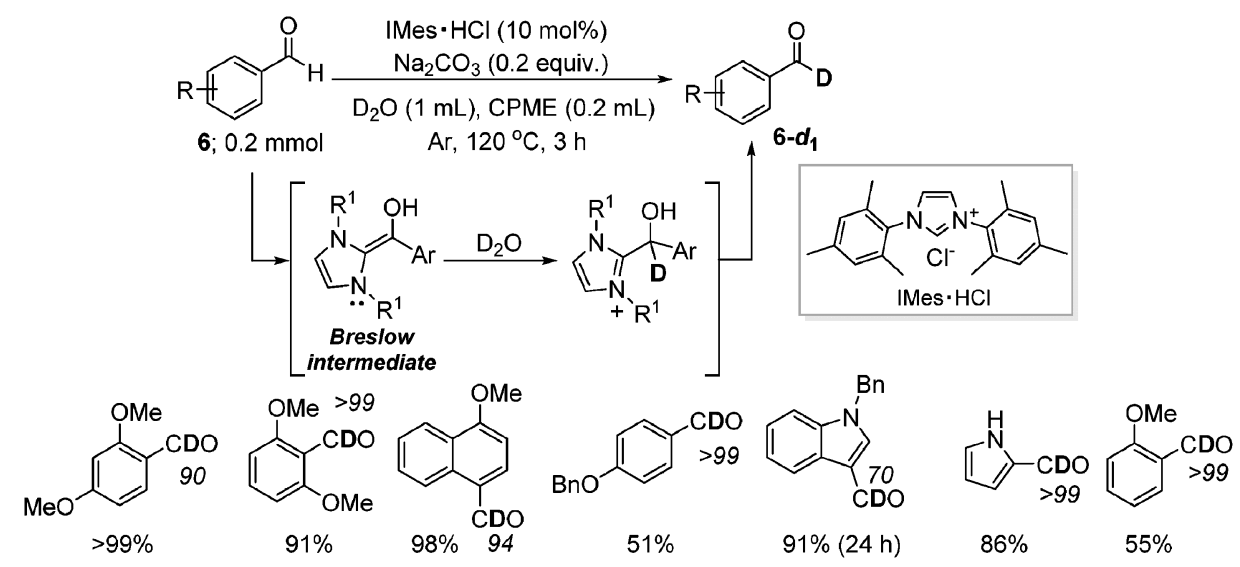

Fig. 4. Direct Deuteration of Aromatic Aldehydes

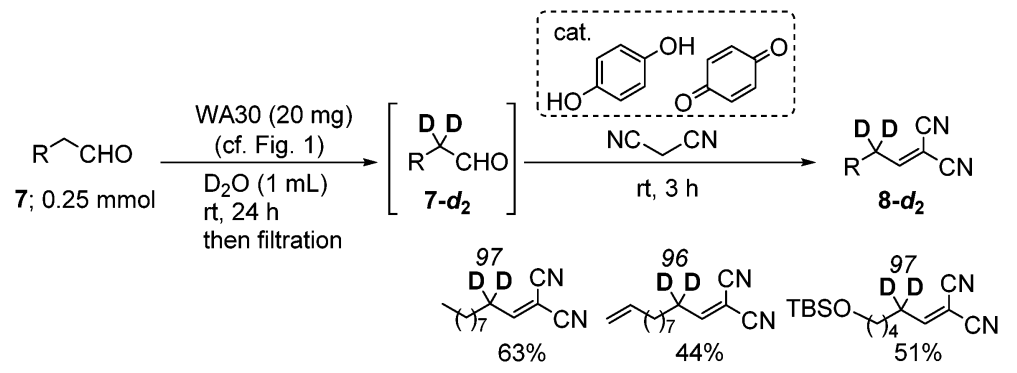

Fig. 5. Synthesis of $\gamma$-Deuterium-incorporated $\alpha, \beta$-unsaturated Nitrile Derivatives

物（5- $\left.\boldsymbol{d}_{\mathbf{2}}\right)$ を合成することができた $[\mathrm{Fig} .3(\mathrm{~b})] .{ }^{18)}$ （重）水中で進行する不斉ニトロアルドール反応と しても有用である。 また，触媒であるWA30 やキ ニーネ誘導体は，再使用しても触媒活性を損なうこ となく所望の反応が進行することを確認している.

2-3. 芳香族アルデヒドの直接的重水素化 ア ルデヒドは求電子性に富んでおり, 多様な骨格変換 の前駆体として重宝される. 重水素化アルデヒドの 調製には多段階工程が必要とされていたが，われわ れは重水中 $N$-ヘテロ環状カルベン（N-heterocyclic carbene; NHC) を触媒とした直接的芳香族アルデ ヒド（6）の重水素化を達成した（Fig. 4). ${ }^{19 ）}$ 1,3Dimesitylimidazolium chloride（IMes）塩酸塩を力 ルベン前駆体として， $\mathrm{D}_{2} \mathrm{O}$-cyclopentylmethylether （CPME）中塩基を加え加熱・攪挥すると Breslow 中間体が形成され，瞬時に $\mathrm{D}_{2} \mathrm{O}$ と反応することで 目的のモノ重水素化芳香族アルデヒド（6- $\left.\boldsymbol{d}_{1}\right)$ が生 成する. 一般に, Breslow 中間体はもう 1 分子の芳 香族アルデヒド（6）と反応することでベンゾイン へと変換される。 $\mathrm{D}_{2} \mathrm{O}$ が過剩量存在するため, Breslow 中間体は優先的に $\mathrm{D}_{2} \mathrm{O}$ と反応できるもの
と推定している.この研究遂行中に，他グループに より同コンセプトによる NHC 触媒的アルデヒ ド- $d_{1}$ 体合成が報告された。 ${ }^{24)}$ 重水素化技術の開発 が世界中で注目されていることが窥える.

\section{2-4. 脂肪族アルデヒドの $\alpha$ 位重水素化に続くマ} ロノニトリルを用いた Knoevenagel 反応前述し たように，脂肪族アルデヒド（7）の $\alpha$ 位は重水中 スチレン系塩基性樹脂 WA30 を触媒とすることで 効率的に重水素化され，2つの重水素原子が導入さ れた脂肪族アルデヒド (Fig. 5, 7- $\left.\boldsymbol{d}_{2}\right)$ が調製される. 一般に，アルデヒド $\alpha$ 位水素の酸性度が高いた め, 酸性並びに塩基性条件で容易に活性化される. そのため， 7- $\boldsymbol{d}_{\mathbf{2}}$ の重水素原子を維持したまま他の骨 格に変換することは困難である。一般に，アルデヒ ドに対するマロノニトリルを用いた Knoevenagel 縮 合は有機溶媒中塩基を触媒として実施される。 そこ でわれわれは，Knoevenagel 縮合を中性に近い条件 下水中で活性化できる触媒系を確立することとし た．その結果，ヒドロキノンとベンゾキノンを 1 対 1 で触媒量添加すると，所望の Knoevenagel 縮合が 効率よく進行することを見い出した（Fig. 5). ${ }^{20)}$ そ 
こで，あらかじめ脂肪族アルデヒド（7）の $\alpha$ 位を $\mathrm{D}_{2} \mathrm{O}$ 中 WA30 を触媒として重水素化し，得られた 7- $\boldsymbol{d}_{\mathbf{2}}$ に対してヒドロキノン・ベンゾキノン共触媒存 在下マロノニトリルを添加すると, 所望の $\gamma$ 位に重 水素原子が導入された $\alpha, \beta$-不飽和ニトリル $\left(\mathbf{8}-\boldsymbol{d}_{2}\right)$ を合成することができた.

\section{3. おわりに}

われわれは，有機触媒を用いた有機分子への位置 選択的重水素原子導入法を開発した。これら重水素 化成績体は官能基変換性に優れており，有用な合成 ビルディングブロックとなる，その一例として，パ ラジウム触媒を用いた還元的変換法も確立した。安 価な $\mathrm{D}_{2} \mathrm{O}$ を重水素源かつ溶媒として用いるため, 一般に有機反応には不利とされる（重）水中での反 応を達成する必要がある。まだ研究の初期段階では あるが，多様な重水素原子導入法を開発し，重水素 化医薬品等の価值ある化合物の創製に向けて今後も 精進したい.

謝辞本誌で記載した研究内容は，岐阜薬科大 学薬品化学研究室で行った成果であり, 御助言・御 鞭撻を賜りました佐治木弘尚教授並びに精力的に研 究を実施してくれた学生諸氏に深謝致します。ま た, 研究支援頂いてます学術変革領域研究 (B) • 重水素学に感謝申し上げます.

利益相反＼cjkstart開示すべき利益相反はない.

\section{REFERENCES}

1) Atzrodt J., Derdau V., Kerr W. J., Reid M., Angew. Chem. Int. Ed., 57, 1758-1784 (2018).

2) Sawama Y., Akutsu K., Sajiki H., Farumashia, 56, 391-395 (2020).

3) Dodo K., Sato A., Tamura Y., Egoshi S., Fujiwara K., Oonuma K., Nakao S., Terayama N., Sodeoka M., Chem. Commun., 57, 2180-2183 (2021).

4) Kojima T., Yamada H., Saito Y., Nawa T., Isobe M., Yamamoto T., Aoki D., Matsushita Y., Fukushima K., Skin Res. Technol., 21, 295-301 (2015).

5) Atzrodt J., Derdau V., Kerr W. J., Reid M., Angew. Chem. Int. Ed., 57, 3022-3047
(2018).

6) Sawama Y., Monguchi Y., Sajiki H., Synlett, 23, 959-972 (2012).

7) Valero M., Derdau V., J. Labelled Compd. Radiopharm., 63, 266-280 (2020) .

8) Grocholska P., Bachor R., Molecules, 26, 2989 (2021).

9) Sawama Y., Yuki Gosei Kagaku Kyokai Shi, 79, 188-196 (2021).

10) Sawama Y., Park. K., Yamada T., Sajiki H., Chem. Pharm. Bull., 66, 21-28 (2018) .

11) Sawama Y., Yamada T., Yabe Y., Morita K., Shibata K., Shigetsura M., Monguchi Y., Sajiki H., Adv. Synth. Catal., 355, 1529-1534 (2013).

12) Sawama Y., Nakano A., Matsuda T., Kawajiri T., Yamada T., Sajiki H., Org. Process Res. Dev., 23, 648-653 (2019).

13) Yamada T., Sawama Y., Shibata K., Morita K., Monguchi Y., Sajiki H., RSC Adv., 5, 13727-13732 (2015).

14) Yamada T., Park K., Yasukawa N., Morita K., Monguchi Y., Sawama Y., Sajiki H., $A d v$. Synth. Catal., 358, 3277-3282 (2016) .

15) Park K., Matsuda T., Yamada T., Monguchi Y., Sawama Y., Doi N., Sasai Y., Kondo S., Sawama Y., Sajiki H., Adv. Synth. Catal., 360, 2303-2307 (2018).

16) Yabe Y., Sawama Y., Monguchi Y., Sajiki H., Chem. Eur. J., 19, 484-488 (2013).

17) Yamada T., Park K., Monguchi Y., Sawama Y., Sajiki H., RSC Adv., 5, 92954-92957 (2015).

18) Yamada T., Kuwata M., Takakura R., Monguchi Y., Sajiki H., Sawama Y., Adv. Synth. Catal., 360, 637-641 (2018) .

19) Sawama Y., Miki Y., Sajiki H., Synlett, 31, 699-702 (2020).

20) Takakura R., Koyama K., Kuwata M., Yamada T., Sajiki H., Sawama Y., Org. Biomol. Chem., 18, 6594-6597 (2020).

21) Sajiki H., Kurita T., Esaki H., Aoki F., Maegawa T., Hirota K., Org. Lett., 6, 3521-3523 (2004).

22) Yabe Y., Yamada T., Nagata S., Sawama Y., Monguchi Y., Sajiki H., Adv. Synth. Catal., 354, 1264-1268 (2012).

23) Yabe Y., Sawama Y., Yamada T., Nagata S., Monguchi Y., Sajiki H., ChemCatChem, 5, 
2360-2366 (2013).

24) Geng H., Chen X., Gui J., Zhang Y., Shen Z.,
Qian P., Chen J., Zhang S., Wang W., Nat. Catal., 2, 1071-1077 (2019). 